\title{
BMJ Open Cohort profile: targeted antenatal screening for haemoglobinopathies in Basel
}

\author{
Gabriela Amstad Bencaiova (D) , Franziska Geissler, Irene Hoesli
}

To cite: Amstad

Bencaiova G, Geissler F, Hoesli I. Cohort profile: targeted antenatal screening for haemoglobinopathies in Basel. BMJ Open 2020;10:e035735. doi:10.1136/ bmjopen-2019-035735

- Prepublication history for this paper is available online. To view these files, please visit the journal online (http://dx.doi. org/10.1136/bmjopen-2019035735).

Received 22 November 2019 Revised 16 March 2020 Accepted 26 May 2020
Check for updates

(c) Author(s) (or their employer(s)) 2020. Re-use permitted under CC BY-NC. No commercial re-use. See rights and permissions. Published by BMJ.

Department of Obstetrics and Antenatal Care, University Hospital of Basel, Basel, Switzerland

Correspondence to Dr Gabriela Amstad Bencaiova; gabriela.amstad@usb.ch

\section{ABSTRACT}

Purpose The pregnancy cohort was established to examine the prevalence and variety of haemoglobinopathies in a high-risk group of pregnant women.

Participants The pregnancy cohort is located in the Department of Obstetrics and Antenatal Care, University Hospital of Basel. The pregnant women were recruited in the first trimester between June 2015 and May 2019. Family origin questionnaires were used to screen pregnant women for the risk of a haemoglobin variant. Based on the questionnaire, pregnant women were divided into two groups: women with a high risk and women with a low risk of a haemoglobin variant. In women with a high risk, red blood cell indices, iron status and chromatography were conducted.

Findings to date 1785 pregnant women were recruited. Out of the 1785 women, 929 were identified as a part of the high-risk group. Due to the missing data of 74 pregnant women with a high risk, the final analysis was conducted in the remaining 855 women. The prevalence of haemoglobinopathies in the high-risk group was $14.5 \%$ (124/855).

Future plans This cohort will be used to: (1) implement the screening in prenatal care in Basel; (2) recommend the screening among pregnant women with a high risk of a haemoglobin variant in Switzerland; (3) improve prenatal and neonatal care in patients with a haemoglobin variant; (4) examine adverse pregnancy outcomes in women with a haemoglobin variant and (5) reduce maternal and neonatal morbidity and mortality in the future.

Trial registration number ClinicalTrials.gov Registry (NCT04029142).

\section{INTRODUCTION}

Haemoglobinopathies are among the most common inherited disorders worldwide. As recommended by the WHO, screening and genetic counselling for haemoglobin (Hb) disorders should be an intrinsic part of healthcare in most countries. ${ }^{1}$ Two factors have recently highlighted the need for a more coordinated approach to diagnosis and management of haemoglobinopathies. First, the globalisation of migration flows has increased cultural diversity, bringing to Europe populations from areas with a high prevalence of haemoglobinopathies, and

\section{Strengths and limitations of this study}

- For the first time, to the best of our knowledge, a prospective study has been conducted to examine the prevalence and the variety of haemoglobinopathies among pregnant women in Switzerland.

- The limitation of our study is the lack of conducting of a high-performance liquid chromatography and molecular analysis in all women. However, conducting a universal screening would not be cost effective in low-risk pregnant women.

The prevalence of $14.5 \%$ in the high-risk group of pregnant women confirms an increasing significance of screening for haemoglobinopathies in this group of patients.

- Our findings provide new insights into the prevalence of haemoglobinopathies and have important implications in the health service within Switzerland.

second, there is an increasing number of patients requiring health services. ${ }^{2-6}$

In the publication 'A Roadmap for European Haematology Research', 7 the European Haematology Association in 2016 recommended undertaking detailed epidemiological studies in all countries, particularly in Western Europe, as a prerequisite for the implementation of effective prevention programmes. Since then different policies for the antenatal and neonatal screening for haemoglobinopathies have been adapted in Europe, yet the data covering affected patients are not available to every country. ${ }^{8}$ There are a few countries with evidence of increasing numbers of patients; however, planning national strategies of increasing number of patients has not been considered at this time to the best of our knowledge. ${ }^{8}$ Although haemoglobinopathies have increased significantly in Switzerland in recent years, there is no routine prenatal and/or neonatal screening for haemoglobinopathies. Therefore, since 2015, we have been conducting targeted prenatal screening at the University Hospital of Basel to investigate the current 
prevalence of haemoglobinopathy and improve prenatal care in these patients.

\section{Cohort description}

A prospective, cross-sectional study was conducted in the Department of Obstetrics and Antenatal Care, University Hospital of Basel, between June 2015 and May 2019. Pregnant women were recruited in the first trimester from our outpatients' department. Family origin questionnaires were used to screen pregnant women for the risk of haemoglobinopathies in the first trimester (figure 1).
The family origin questionnaire was adopted from the National Health Screening Sickle Cell and Thalassaemia Screening Programme in England figure 1. Based on the questionnaire, pregnant women were divided into two groups: women with a high risk and women with a low risk of haemoglobinopathies.

In women with a high risk, red blood cell (RBC) indices, iron status and high-performance liquid chromatography (HPLC) were conducted. For women identified as carriers, their partner was also tested for

\title{
$y$
Basel \\ Department of Obstetrics
}

\begin{abstract}
„Family origin questionnaire for screening of thalassaemia, sickle cell anaemia and other forms of haemoglobinopathy"

To our pregnant patients

Haemoglobinopathies are among the most common inherited disorders worldwide. As a result of the migration of people from countries with high prevalence of haemoglobin disorders, laboratory diagnosis is of growing importance in Switzerland. Countries C, D, E, F and G (See below; in red) have a high prevalence of haemoglobinopathies. Testing for haemoglobinopathies should be conducted in these women.
\end{abstract}

What are your family origins?

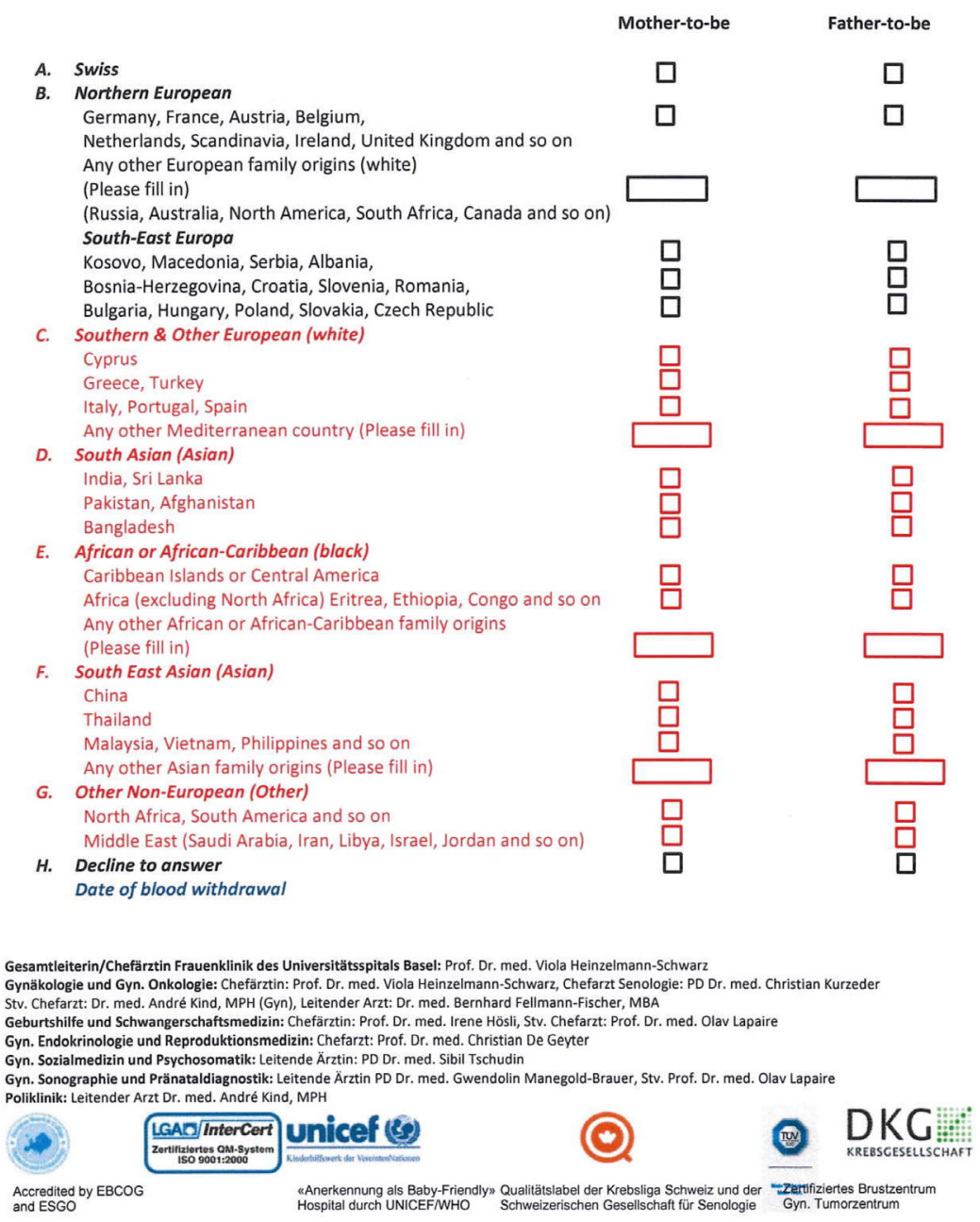

Figure 1 The family origin questionnaire. 


\begin{tabular}{ll}
\hline $\begin{array}{l}\text { Table } 1 \\
(\mathrm{n}=855)\end{array}$ & Haematological data and serum iron status \\
\hline $\mathrm{Hb}(\mathrm{g} / \mathrm{L})$ & $121 \pm 12.7(68-174)$ \\
$\mathrm{RBC}\left(\times 10^{6} / \mu \mathrm{L}\right)$ & $4.18 \pm 0.45(2.2-6.2)$ \\
\hline $\mathrm{MCV}(\mathrm{fL})$ & $84.5 \pm 7.4(59-122.2)$ \\
$\mathrm{MCH}(\mathrm{pg})$ & $24.2 \pm 3.7(19.2-32.9)$ \\
\hline $\mathrm{HRC}(\%)$ & $0.8(0-58.2)$ \\
\hline $\mathrm{RDW}(\%)$ & $14.2 \pm 1.9(11.7-32.1)$ \\
\hline Reticulocytes $(\%)$ & $18.5 \pm 5.1(7-38)$ \\
\hline Ferritin $(\mu \mathrm{g} / \mathrm{L})$ & $40(4-5607)$ \\
\hline CRP $(\mathrm{mg} / \mathrm{L})$ & $4.1(0.3-89.9)$ \\
\hline
\end{tabular}

CRP: C- reactive protein

$\mathrm{Hb}$, haemoglobin; $\mathrm{HRC}$, hypochromic red blood cells; $\mathrm{MCH}$, mean corpuscular haemoglobin; MCV, mean corpuscular volume; RBC, red blood cell; RDW, RBC distribution width.

haemoglobinopathy, irrespective of family origin. In cases where alpha thalassaemia was suspected based on haematological parameters (mean corpuscular haemoglobin $(\mathrm{MCH})<27 \mathrm{pg}$ regardless of iron status), ${ }^{9}$ a molecular analysis was performed. If both were carriers of haemoglobinopathies, genetic counselling was recommended and an antenatal genetic testing via choriovillous sampling or amniocentesis was discussed with the patient.

Inclusion criteria were patients aged $\geq 18$ years and having a gestational age at recruitment between 11 and 14 weeks. The primary outcome was the prevalence of haemoglobinopathies in pregnant women. Secondary outcome measures included a variety of haemoglobinopathies, the prevalence of anaemia, iron deficiency anaemia and iron deficiency.

\section{Haematological assessment}

Screening for anaemia in pregnancy is generally recommended in Switzerland, including the RBC count and ferritin at the end of the first trimester. ${ }^{10}$ Therefore, blood samples were collected by venepuncture. All blood measurements (blood count, CRP (C- reactive protein), ferritin and HPLC) were conducted in the Department of Laboratory Medicine, University Hospital of Basel.

$\mathrm{Hb}, \mathrm{RBC}$ count, haematocrit, mean corpuscular volume (MCV), MCH, hypochromic RBCs (HRC) and RBC

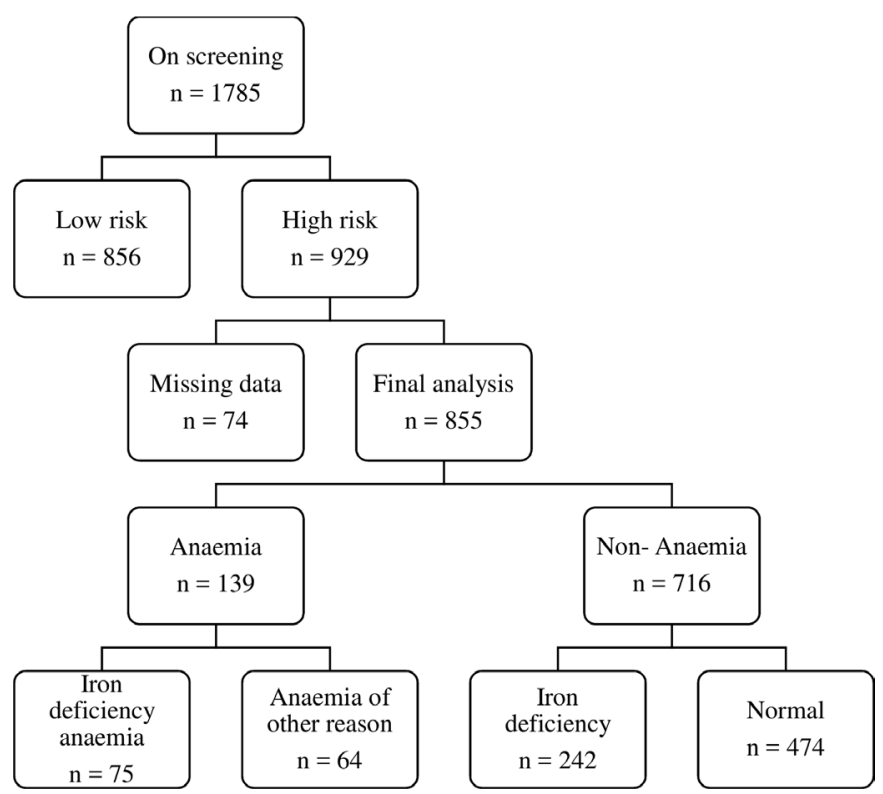

Figure 2 Pregnant women on screening, on testing and completion. Allocation of pregnant women with a high risk of haemoglobinopathy according to haemoglobin and serum ferritin.

distribution width (RDW) were measured using a haematology analyser. The MCH was automatically calculated from $\mathrm{Hb}$ and RBC counts. Haematological parameters were measured using an ADVIA haematology analyser system (Bayer Diagnostics, Leverkusen, Germany).

Serum ferritin was assessed by chemiluminescence immunoassay and CRP was assessed by immunoturbidimetry. The Hbs were separated and processed by an HPLC using a model-II machine from the company Bio-Rad.

\section{Study criteria}

Based on the guidelines from the Centre for Disease Control (CDC, USA), anaemia in pregnancy was defined as an $\mathrm{Hb}$ of less than $110 \mathrm{~g} / \mathrm{L}$ in the first trimester. ${ }^{11}$ Iron deficiency (ID) was defined as a serum ferritin of less than $30 \mu \mathrm{g} / \mathrm{L}$. Iron deficiency anaemia (IDA) was defined as an $\mathrm{Hb}$ of less than $110 \mathrm{~g} / \mathrm{L}$ and serum ferritin of less than $30 \mu \mathrm{g} / \mathrm{L}$. Anaemia of other aetiology was defined as an $\mathrm{Hb}$ of less than $110 \mathrm{~g} / \mathrm{L}$ and serum ferritin $30 \mu \mathrm{g} / \mathrm{L}$ or more.

The determination of haemoglobin $\mathrm{A}_{2}\left(\mathrm{HbA}_{2)} \geq 3.5 \%\right.$ was indicative of beta thalassaemia. ${ }^{9}{ }^{12}$ In some cases of

Table 2 The haematological data of the four groups $(n=855)$

\begin{tabular}{|c|c|c|c|c|c|c|c|c|}
\hline & Group 1 & & Group 2 & & Group 3 & & Group 4 & \\
\hline $\mathrm{Hb}(\mathrm{g} / \mathrm{L})$ & $125(8.1)$ & $110-155$ & $124(8.5)$ & $110-148$ & $100(8.1)$ & 75-109 & $100(8.4)$ & 68-109 \\
\hline CRP (mg/L) & 3.9 & $0.3-89.9$ & 4 & $0.3-141$ & 5.4 & $1-27.6$ & 5.1 & $1.2-19.4$ \\
\hline
\end{tabular}

Group 1: normal (474); group 2: iron deficiency (242); group 3: iron deficiency anaemia (75) and group 4: anaemia of other causes (64). CRP, C- reactive protein; $\mathrm{Hb}$, haemoglobin; ID, iron deficiency; IDA, iron deficiency anaemia. 
Table 3 Types of haemoglobin variants

\begin{tabular}{|c|c|}
\hline Haemoglobin variant & $\begin{array}{l}\text { Number } \\
\text { of } \\
\text { patients } \\
(\%)\end{array}$ \\
\hline Beta thalassaemia & $42(33.9)$ \\
\hline Alpha thalassaemia trait & $39(31.5)$ \\
\hline Heterozygous alpha ${ }^{+}$thalassaemia & 23 \\
\hline Homozygous alpha $^{+}$thalassaemia & 12 \\
\hline Heterozygous alpha ${ }^{0}$ thalassaemia & 4 \\
\hline Sickle cell anaemia & $23(18.5)$ \\
\hline Heterozygous & 18 \\
\hline Homozygous & 5 \\
\hline Other haemoglobins & $12(9.7)$ \\
\hline Heterozygous delta thalassaemia & 3 \\
\hline Haemoglobin E & 6 \\
\hline Heterozygous haemoglobin $\mathrm{E}$ & 5 \\
\hline Homozygous haemoglobin E & 1 \\
\hline Heterozygous haemoglobin C & 1 \\
\hline Heterozygous haemoglobin D & 2 \\
\hline Compound haemoglobins & $8(6.4)$ \\
\hline $\begin{array}{l}\text { Heterozygous sickle cell anaemia/ } \\
\text { heterozygous alpha thalassaemia }\end{array}$ & 4 \\
\hline $\begin{array}{l}\text { Heterozygous sickle cell anaemia/homozygous } \\
\text { alpha thalassaemia }\end{array}$ & 1 \\
\hline $\begin{array}{l}\text { Homozygous sickle cell anaemia/heterozygous } \\
\text { alpha thalassaemia }\end{array}$ & 1 \\
\hline $\begin{array}{l}\text { Heterozygous haemoglobin C/homozygous } \\
\text { alpha thalassaemia }\end{array}$ & 1 \\
\hline $\begin{array}{l}\text { Heterozygous haemoglobin E/heterozygous } \\
\text { alpha thalassaemia }\end{array}$ & 1 \\
\hline
\end{tabular}

beta thalassaemia (borderline elevated $\mathrm{HbA}_{2}$ and in cases where both partners are carriers for beta thalassaemia), confirmation by molecular analysis was conducted. $\mathrm{Hb}$ variants $(\mathrm{C}, \mathrm{D}, \mathrm{E}, \mathrm{F}$ and $\mathrm{S})$ were identified using the HPLC technique. A sickle solubility test was performed whenever $\mathrm{Hb} \mathrm{S}$ was detected by HPLC.

A genetic test was performed in women with $\mathrm{MCH}$ $<27 \mathrm{pg}$ to confirm alpha thalassaemia. ${ }^{9}$ Two forms of alpha thalassaemia trait were described; the homozygous alpha trait if the missing genes were on opposite chromosomes and the heterozygous alpha trait if both missing genes were on the same chromosomes.

Anaemia of other aetiologies was found to be primarily caused by haemoglobinopathies, diseases of the liver or kidney, HIV infection, antiphospholipid syndrome and so on.

Statistical analysis was conducted using STATA V.12.0 (Stata Corporation, College Station, Texas, USA). Blood indices, CRP and serum ferritin were expressed as mean $\pm \mathrm{SD}$ and range, or median and range.

\section{Dissemination}

The findings of this study will be published in a peerreviewed journal and presented at national scientific conferences to disseminate the results to academic and health professional audiences. In addition, they will be made available to the participants and to the wider public on our website at the time of publication.

\section{Patient and public involvement}

The patients and the public were neither involved in developing the hypothesis, the specific aims or the research question, nor were they involved in developing the plan for design or implementation of the study.

\section{Findings to date}

In brief, 1785 pregnant women were recruited. Out of 1785 women, 929 were identified as a part of the high-risk group. Due to the missing data of 74 pregnant women within the high-risk group, the analysis was conducted in 855 women (figure 2). The mean gestational age at the time of screening was $12.3 \pm 2$ weeks. The mean of $\mathrm{Hb}$ was $121 \pm 13 \mathrm{~g} / \mathrm{L}(68-174 \mathrm{~g} / \mathrm{L})$ and the median of ferritin was $40 \mu \mathrm{g} / \mathrm{L}(4-5607 \mu \mathrm{g} / \mathrm{L})$ (table 1$)$.

There were 139 anaemic women $(139 / 855 ; 16.3 \%)$; namely, iron deficiency anaemia was identified in 75 women $(75 / 855 ; 8.8 \%)$ and anaemia of other aetiology in 64 women $(64 / 855 ; 7.5 \%)$ (figure 2$)$. There were 242 women with iron deficiency $(242 / 855 ; 28.3 \%)$. The mean of $\mathrm{Hb}$, serum ferritin and CRP of each group is presented in table 2.

Most of the pregnant women in the screening originated from Africa (primarily Eritrea), Turkey, India and the Middle East (primarily Syria). The prevalence of haemoglobinopathies was $14.5 \%$ in the high-risk group $(124 / 855)$ and $6.95 \%$ for all patients $(124 / 1785)$. There were 5 women with sickle cell anaemia, 18 with the sickle cell trait, 39 with the alpha thalassaemia (4 women with heterozygous alpha ${ }^{0}$ thalassaemia trait, 23 with heterozygous alpha ${ }^{+}$thalassaemia and 12 with homozygous alpha ${ }^{+}$ thalassaemia), 42 with heterozygous beta thalassaemia, 12

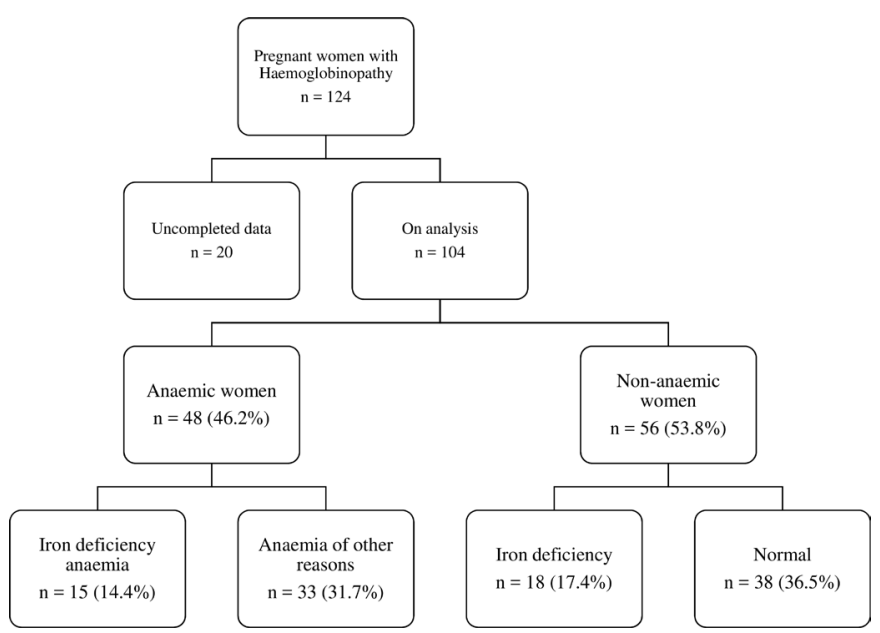

Figure 3 Allocation of pregnant women with haemoglobin $\mathrm{Hb}$ ) variants according to $\mathrm{Hb}$ and serum ferritin. 
with other $\mathrm{Hb}$ variants and 8 women with an $\mathrm{Hb}$ variant and alpha thalassaemia (table 3).

In pregnant women with an $\mathrm{Hb}$ variant, the mean of $\mathrm{Hb}$ was $111 \pm 14 \mathrm{~g} / \mathrm{L}(79-162 \mathrm{~g} / \mathrm{L})$ and the median of ferritin was $54 \mu \mathrm{g} / \mathrm{L}(5-5607 \mu \mathrm{g} / \mathrm{L})$. There were 48 anaemic women with an $\mathrm{Hb}$ variant $(48 / 104 ; 46.2 \%)$ and 56 were non-anaemic $(56 / 104 ; 53.8 \%)$ (figure 3). Of the identified women with an $\mathrm{Hb}$ variant, 15 showed iron deficiency anaemia in the first trimester $(15 / 104$; $14.4 \%$ ) (figure 3 ). There were 33 women with an $\mathrm{Hb}$ variant and concomitant iron deficiency. In 71 pregnant women with an $\mathrm{Hb}$ variant, the ferritin was $\geq 30 \mu \mathrm{g} / \mathrm{L}$. In 12 women, the ferritin was $\geq 150 \mu \mathrm{g} / \mathrm{L}(12 / 104 ; 11.5 \%), 2$ women presented alpha thalassaemia, 6 beta thalassaemia and 4 homozygous sickle cell anaemia. There was a very low mean of MCV and MCH in the group of women with alpha and beta thalassaemia (mean MCV 70 $\pm 7 \mathrm{fL}$ (59-88) and MCH $23 \pm 3$ pg (16.3-31.6)). In 23 pregnant women $(23 / 124)$, an $\mathrm{Hb}$ variant was previously diagnosed and 101 women were diagnosed based on our screening $(101 / 124)$.

\section{DISCUSSION}

Population movements affect the distribution of inherited disorders of $\mathrm{Hb}$ within countries, with previously isolated populations increasingly interacting and large numbers of migrants moving from rural to urban areas; the complexity of genotypes can be observed as newly introduced variants may interact with local ones to create more or less severe phenotypes. ${ }^{13}$

The prevalence of haemoglobinopathies of $6.95 \%$ $(124 / 1785)$ in total in our study group corresponds to an overall average of $8 \% .{ }^{14}$ In the high-risk group of women, the prevalence of haemoglobinopathies was twice as high $(124 / 855 ; 14.5 \%)$. Using the family origin questionnaire, we identified a group of pregnant women with haemoglobinopathies, which might have otherwise been overlooked. Half of the pregnant women with haemoglobinopathies were non-anaemic and two-thirds of them had normal iron status in the first trimester. One-third of the women with haemoglobinopathies showed anaemia with normal iron status in the first trimester. The majority of pregnant women in the screening originated from Africa, Turkey, the Middle East and India. Due to the political changes significant more women were reported from Syria and Eritrea in the last few years.

In the UK, where there is a well-established, linked neonatal and antenatal screening programme for haemoglobinopathies, a downward trend in reported screenpositive results is discernible in some areas. ${ }^{8}$ In contrast, Germany, Italy and France have recently been accepting large numbers of refugees and have faced a dramatic increase in their patient numbers since $2014 .{ }^{8}$ With the exception of Belgium, the UK, Cyprus, Greece, Germany and Spain, no national registry exists for haemoglobinopathies in European countries. ${ }^{8}$ According to the Organisation for Economic Co-operation and Development, the percentage of foreign-born populations within the European Union in 2008 ranged from 4\% in Finland to $37 \%$ in Luxembourg. ${ }^{14}$ Switzerland has one of the highest proportions of foreigners in its midst among all nations: $24.6 \%$ in $2016 .^{14}$

European countries with a high prevalence of haemoglobinopathies have adopted a neonatal screening programme (France, Belgium, the Netherlands and Spain), an early antenatal screening programme (Sweden and Italy), a linked neonatal and antenatal screening programme (the UK) or a preconceptional, premarital screening programme (Cyprus, Greece and Turkey). Antenatal screening programmes are generally assessed by the uptake of prenatal diagnosis, optimal care management and/or the allowance to terminate affected pregnancies.

The limitation of our study is the lack of HPLC in all women. However, conducting universal screening would not be cost effective in low-risk pregnant women. The choice of the screening method is based on cost effectiveness, and it has been demonstrated that at a prevalence of at least 16 sickle cell traits $/ 1000$, there is no significant cost difference between universal and targeted screening programmes. Therefore, targeted antenatal screening is recommended in Switzerland. On the other hand, it would be impossible to detect women with a sickle cell trait by using the full blood count alone for screening due to normal RBC parameters in these patients.

Our findings will be used to further implement the screening in prenatal care in Basel and will be recommended among all pregnant women with a high risk of haemoglobinopathies in Switzerland. Early recognition of $\mathrm{Hb}$ variants in women enables early testing of partners and provides the opportunity for further testing where required. Thereby, the ability to improve prenatal and neonatal care in these patients and to reduce the number of children with severe clinically relevant $\mathrm{Hb}$ variants can be offered.

Contributors $\mathrm{GAB}$ is the principal investigator who designed the study, carried out the quantitative analysis and drafted the article. FG collected the data. IH reviewed and edited the manuscript. All authors have read and approved the final manuscript.

Funding The authors have not declared a specific grant for this research from any funding agency in the public, commercial or not-for-profit sectors.

Competing interests None declared.

Patient consent for publication Not required.

Ethics approval The study received ethical approval from the local ethics committee in Basel (ID 2019-01065). All members of the research team were aware of the guidelines for good clinical practice.

Provenance and peer review Not commissioned; externally peer reviewed.

Data availability statement All data relevant to the study are included in the article or uploaded as supplementary information. After publication of the study individual, anonymous participant data, including variable keys, will be available from the corresponding author on request. Researchers may request data to repeat the analyses or use the data for secondary analyses (eg, systematic review and meta-analysis).

Open access This is an open access article distributed in accordance with the Creative Commons Attribution Non Commercial (CC BY-NC 4.0) license, which permits others to distribute, remix, adapt, build upon this work noncommercially, and license their derivative works on different terms, provided the original work is properly cited, appropriate credit is given, any changes made 
indicated, and the use is non-commercial. See: http://creativecommons.org/ licenses/by-nc/4.0/.

\section{ORCID iD}

Gabriela Amstad Bencaiova http://orcid.org/0000-0002-1661-5056

\section{REFERENCES}

1 Modell B, Darlison M. Global epidemiology of haemoglobin disorders and derived service indicators. Bull World Health Organ 2008;86:480-7.

2 Piel FB, Adamkiewicz TV, Amendah D, et al. Observed and expected frequencies of structural hemoglobin variants in newborn screening surveys in Africa and the middle East: deviations from HardyWeinberg equilibrium. Genet Med 2016;18:265-74.

3 Cortés-Castell E, Palazón-Bru A, Pla C, et al. Impact of prematurity and immigration on neonatal screening for sickle cell disease. PLOS One 2017;12:e0171604.

4 Inusa BPD, Colombatti R. European migration crises: the role of national hemoglobinopathy registries in improving patient access to care. Pediatr Blood Cancer 2017;64. doi:10.1002/pbc.26515. [Epub ahead of print: 30 Mar 2017].

5 Kunz JB, Cario H, Grosse R, et al. The epidemiology of sickle cell disease in Germany following recent large-scale immigration. Pediatr
Blood Cancer 2017;64. doi:10.1002/pbc.26550. [Epub ahead of print: 06 Apr 2017].

6 Aguilar Martinez P, Angastiniotis M, Eleftheriou A, et al. Haemoglobinopathies in Europe: health \& migration policy perspectives. Orphanet $J$ Rare Dis 2014;9:97.

7 Engert A, Balduini C, Brand A, et al. The European hematology association roadmap for European hematology research: a consensus document. Haematologica 2016;101:115-208.

8 Lobitz S, Telfer P, Cela E, et al. Newborn screening for sickle cell disease in Europe: recommendations from a pan-European consensus conference. Br J Haematol 2018;183:648-60.

9 Ryan K, Bain BJ, Worthington D, et al. Significant haemoglobinopathies: guidelines for screening and diagnosis. $\mathrm{Br} \mathrm{J}$ Haematol 2010;149:35-49.

10 Breymann C, Honegger C, Hösli I, et al. Diagnosis and treatment of iron-deficiency anaemia in pregnancy and postpartum. Arch Gynecol Obstet 2017;296:1229-34.

11 Centers for Disease Control (CDC). Cdc criteria for anemia in children and childbearing-aged women. MMWR Morb Mortal Wkly Rep 1989;38:400-4.

12 The laboratory diagnosis of haemoglobinopathies. Br J Haematol 1998;101:783-92.

13 Piel FB. The present and future global burden of the inherited disorders of hemoglobin. Hematol Oncol Clin North Am 2016;30:327-41.

14 Abel GJ, Sander N. Quantifying global international migration flows. Science 2014;343:1520-2. 